\title{
The Italian 'Taste': The Far-Right and the Performance of Exclusionary Populism During the European Elections
}

\author{
Sara García-Santamaría \\ Ramon Llull University (Spain)
}

This article examines populist leaders' politicisation of food in their social media performances. More precisely, it analyses Matteo Salvini's Instagram posts during the 2019 European elections, and the way food is mobilized for populist and nationalist purposes. The main argument is that food serves as a cultural trope that confers identity, reinforcing social divisions and the terms of national and class belonging. Drawing on Bourdieu's (1984) social critique of taste, political leaders have traditionally placed themselves on the side of a distant gastronomic culture; that of a high-end elite. However, populist leaders perform a twofold role, attempting to present themselves as part of the common people and distancing themselves from the traditional elite. This change in social positioning is reflected in their social media accounts, often posting "authentic" glimpses of their cultural practices, such as cooking and eating. Methodologically, this paper uses a mixed-methods concurrent design, combining digital ethnography and visual rhetoric analysis for examining both the discursive and the aesthetic clues that construct Salvini's social positioning towards taste. Through food, being Italian becomes a matter of constructing Italian authenticity against the national intellectual and political elite, but also against the European value-building project.

Keywords: right-wing populism, nationalism, food, European elections.

\footnotetext{
$\mathrm{A}$ nthropological studies have long demonstrated the role of food in conferring identity, status and belonging (Elliot, 2008). Drawing on a discourse theoretical approach to populism (Laclau and Mouffe, 1984; Carpentier and Cleen, 2007; Cleen and Stavrakakis, 2017), I am concerned with the ideological function of food insofar it helps sustaining nationalist and exclusionary populist discourses. This work analyses the notion of "food populism", or populism through food, in the official Instagram account of Matteo Salvini during the
} 
2019 European Union elections campaign. The main argument is that Salvini uses food as a cultural trope that brings him closer to the people while constructing boundaries of national belonging and exclusion. Just as Hitchcock's Rear Window, Salvini's food posts offer his followers a window through which they can observe the privacy of "our neighbourhoods and those outside them" (Bell and Valentine, 1997: 15). Therefore, the politicisation of food allows the leader to delineate the spatial, temporal and moral grounds of being Italian.

Food, as a cultural product, helps creating/reinforcing social divisions that organize our image of the social world and our place on it. In his social critique of taste, Bourdieu (1984: 466) considers that it "functions as a sort of social orientation, a 'sense of one's place'". This idea is similar to Ranciere's (2010) notion of a social distribution of places between the proper and the improper. "By categorizing foods into what's good to eat and what is not, a cuisine helps a society's members define themselves. To eat appropriate foods is to participate in a particular group; eat inappropriate foods and you're an outsider. Like language, a cuisine is a medium by which a society establishes its special identity" (Belasco, 1989: 44).

Bourdieu considers that our placement in society can be performed in regard to taste, depending on antagonistic positions that classify people and objects on the side of the dominant elite, which he calls the bourgeoisie, or as part of the dominated masses. Instagram food posts are then a useful tool for performing a given national and social class identity based on one's position towards taste (LeBesco and Naccarato, 2008: 224). This means that politicians need to consciously choose whether they constructs their social media persona around proper or improper places, national or ethnic dishes, elitist or popular signifiers, high or low culture, fine or coarse aesthetics, light or heavy meals, unique or common ingredients, brilliant or dull cooking skills (Bourdieu, 1984: 468).

This work examines Matteo Salvini's Instagram posts leading to the 2019 European Elections. Methodologically, the project uses a mixed methods concurrent design, using digital ethnography as the main approach for collecting the data. Digital ethnography aims at making sense of individuals' everyday realities, and the way they ascribe meaning to them on digital spaces. This approach allows examining politicians' construction of identity selfrepresentations, affective communities as expressed on digitally based platforms. The analysis was conducted in two steps: first, a content analysis of Salvini's posts on Atlas.ti, drawing on sensitising concepts from discourse theoretical analysis - such as discourse, populism or empty signifiers, as well as an inductive approach to the data. This was then systematised through a visual rhetoric analysis (Kędra and Sommier, 2018) of food posts, looking at both the rhetorical and visual strategies that Salvini uses for constructing of boundaries of inclusion and exclusion. While the official political campaign started on May 10th, the Italian leader got a head start. Therefore, the analysis runs for two months, from April 6th to June 7th, 2019, which is the lapse of time in which Salvini uses the EU elections slogan "Verso l'Europa del buonsenso! Il popoli rialzano la testa" or "Towards the Europe of the common sense! The people raise its head" on his Instagram account, @matteosalviniofficial. During that time, Salvini published 
36 food-related posts. The 2019 European Union Elections prove an interesting "critical discursive moment" (Carvalho, 2008: 166) for examining the use of everyday cultural tropes, such as food, for constructing an exclusionary populist discourse based on the promotion of national values against transnational valuebuilding projects.

\section{MATTEO SALVINI AND THE ITALIAN “TASTE”}

This article argues that Matteo Salvini's use Instagram for positioning himself as a proud and humble Italian gains full sense when it is examined within his discursive universe of populism, exclusionary nationalism and Euroscepticism. During the 2019 European elections, he was serving as Deputy Prime Minister and Minister of the Interior -from June 2018 to September 2019. In a recent study, Engesser et al. (2017) have concluded that populism is endemic to the way in which Italian political leaders use social media, with Matteo Salvini leading in terms of followers and follower interaction. An analysis of Salvini's Facebook posts from 2014 to 2017 shows a predominant focus on immigration, followed by security, and a great appeal to Italian values against European ones (Albertazzi, Giovannini, and Seddone, 2018).

Italian tradition and nationalism are entangled in Salvini's food posts in a way that accentuate the fight between national and foreign interests - such as Italian versus European ones. Just as Salvini campaigns for "made in Italy" products - very much in line with his slogan "Italians First" -, he attacks the foreign countries and institutions who allegedly want to hurt Italian interests. This has sparked more than a "food war". A self-declared fan of Nutella, one day he tells his followers that he no longer eats it because it contains Turkish hazelnuts. When he finds out that the Italian production of hazelnuts is too small for meeting the demand, he takes a step back posing next to a jar of Nutella (@matteosalviniofficial, 6 December 2019) while declaring: “After the complaint that came from Carola Rackete, a slice of bread and Nutella to sweeten the day with a request to Ferrero: buy Italian ingredients, from sugar to hazelnuts, to help our farmers" (La Reppublica, 2019). ${ }^{1}$ In another post, Salvini poses for the press holding a big knife as he cuts a cheese, both proud and threatening in his criticism to the European Union for "outlawing the Made in Italy" and promoting budget cuts to "our agriculture and our fishing" (@matteosalviniofficial, 14 December 2018). Both food polemics serve as an example of Salvini's politicisation of food in a way that reinforces his exclusionary populism, anti-immigration discourse and Euroscepticism.

1 Carola Rackete became the target of Matteo Salvini's anger when the German ship captain, who rescues immigrants at sea for Sea-Watch, docked a rescue ship with 53 migrants in Lampedusa, Italy, without governmental authorisation on June 29, 2019. 
Food is an essential part of our culture and the Mediterranean diet has been part of the UNESCO World Heritage since 2010 (Ascione, 2018). The idea of the Mediterranean, as well as the Made in Italy, brings us back to the notion of territorio, of the conjunction between a unique geography and a unique "culinary capital" that configure the particular "taste" of a place. The territorio is a compendium of agricultural, commercial but also moral and ideological values (Paxson, 2013:191). Matteo Salvini's attachment to his territorio sparks sentiments of pride that are connected to the quality and uniqueness of Italian ingredients and the saper fare of the Italian cooking tradition. The love for food, for the territorio and for the traditional saper fare is something that confers authenticity to Italians in a globalised world drawn by homogenising and standardising forces of late capitalism (Ulin, 2013), but also in the face of a European Union that seeks to erase food borders and promote multicultural food trends.

Food is an important cultural trope for anchoring people to a place and to a community in a global setting (Giovine, 2014), conveying a particular construction of memory. From this, it follows that the notions of comfort food and territorio are useful for nation-building purposes that align with the nationalist and exclusionary goals of right-wing populist leaders who seek the "heritagisation" of culture (Ascione, 2018: 300) — that is, to present cultural tropes in terms of an exclusionary heritage. The politicisation of food can very well serve a populist, anti-elitist communication strategy that brings the leader and the common people together against the bourgeois taste of the traditional political class. The following section will explore the connections between populism and the use of food posts on social media for appealing to "the people" both in terms of class — the common people — and nation — the national people.

\section{WHEN FOOD STANDS FOR THE PEOPLE}

In this study, food is used as a cultural trope easily mobilised by populist leaders in order to advance a particular ideology -in terms of gender, class or national belonging. When Matteo Salvini posts a simple dish of pasta with mozzarella, tomatoes and basil that evokes the colours of the Italian flag, he is invoking the whole nation. Here, food stands for much more than what we visually perceive: it has both an emotional and an ideological appeal. This is because, under a poststructuralist approach, a complete representation of the social world is unachievable, yet we need to represent it somehow in order to make sense of it (Laclau, 2005: 70). The contradiction between an impossible faithful representation of the world and our need to do so with crooked tools is solved by Laclau through the concept of "empty signifier". An "empty signifier" is one that empties itself from its immediate meaning, leaving room for encompassing a broad range of elements (Laclau, 2005: 71) — like a humble dish of Italian pasta.

Some scholars have argued that right and left-wing populist leaders construct "the people" differently, either in national terms, the ethnos, or appealing to social class, the demos (Mudde and Rovira-Kaltwasser, 2013; Waisbord, 2013). However, this article argues that populist discourses of the people go beyond 
right and left divisions. This article follows de Cleen and Stavrakakis (2017) analytical difference between discursive appeals to populism and to nationalism. The scholars argue that populist and nationalist discourse present different articulations of socio-political antagonism. While in nationalist discourse "the people" is mainly represented as belonging to a nation, in populist discourse it is constructed as belonging to a popular social class. Taken to this case study, this means that far-right populist leaders can construct their social media identity by connecting to the national people, but also the common man.

Social media provides an optimal emotional and communicational environment for populist politicians who want to appeal to "the people", independently from their position in the left-right spectrum (Bracciale and Martella, 2017). "Food populism" refers to populist leaders' use of aesthetically rough, simple food as an empty signifier that connects, both culturally and emotionally, with the national common people. This is done against the snobbism associated with the political elite - or the bourgeois taste, and the highly curated aesthetics of foodies (Bourdieu, 1984). The "term 'food porn' is increasingly used to describe the act of styling and capturing food on mobile gadgets, eliciting an invitation to gaze and vicariously consume, and to tag images of food through digital platforms" (Ibrahim, 2015: 2). The notion of excess is then key to "food porn" (Dejmanee, 2015). In opposition to "food porn", Salvini's appeals to tradition, familiarity and austerity bring "food populism" close to "food puritanism": a food removed from all excess and embellishment. ${ }^{2}$ Therefore, "food populism" opposes "food porn" by avoiding both ethnic exoticism and visual sumptuousness.

Appealing to emotions through "food populism" can play an important role in political communication (Soroka, Young, and Balmas, 2015; Eklundh, 2019). Previous research suggests that far-right populist leaders use "food populism" as the political mobilisation of everyday cultural tropes in a way that activates our "visceral" a/effects (García-Santamaría, 2020; Hayes-Conroy and Hayes-Conroy, 2013). The concept of affective polarisation shows that "the people" tend to identify as partisans of a certain group and separate from other groups that they do not identify with (Iyengar and Westwood, 2015). This polarisation would be increased by the affordances of social media because of the absence of norms governing the expression of negative sentiment (ibid.).

Emotions are particularly important for mobilising people's support for right-wing parties. In fact, evoking positive emotions seems to foster user engagement with a post (Klassen et al., 2018). For instance, an emotion analysis of food posts containing the hashtag \#foodporn found that positive sentiments are easily expressed in \#foodporn posts in Southern Europe (including Italy) (Mejova et al., 2015). However, "to eat means to have pleasant (and sometimes

2 Food critic Richard Magee delineates the idea of "food puritanism" in reference to traditional, conservative ways of representing food, such as that of Martha Stewart (in McBride, 2010). 
unpleasant) sensations, to experience special emotions, and to socialize with table companions" (Corvo, 2015: 1-2). While there is a strong body of research on social media, food and positive emotions, scholarship on populism has highlighted the importance of negative ones. The notion of ressentiment refers to the way in which a negative emotion, fear, translates into anger when repressed. Looking at populist strategies of emotionalisation and boundarymaking, Salmela and Von Scheve (2018) argue that ressentiment can be mobilised through identity-evoking cultural tropes, such as food, which can be used for connecting to an audience and, altogether, channel resentment against others.

In fact, invoking negative emotions seems common populist strategy for mobilising the insecurities of the so-called 'losers of modernisation,' which some identify as its main supporters (Salmela and Scheve, 2018; Minkenberg, 2003). The perceived subjective failure of traditional social identities, values and supportnetworks (that is, of social and cultural capital) across the class spectrum can be politically mobilised in a way that "promotes seeking meaning and self-esteem from aspects of identity perceived to be stable and to some extent exclusive, such as nationality, ethnicity, religion, language and traditional gender roles" (Salmela and Scheve, 2018: 434). Therefore, food can become an empty signifier that appeals to stable elements of people's identity, evoking safety, tradition, and authenticity.

Populist strategies of emotionalisation on social media are able to mobilize people through the confrontation of the ingroup to an outgroup, by creating frontiers of identity and belonging (Engesser et al., 2017). In Salvini's Instagram account, everyday cultural tropes such as food, sports jerseys or cats, are used as empty signifiers that draw the followers' attention and connect with them at an emotional level, creating shared emotions of joy, passion and delight. It is the emotional appeal of cultural tropes, their inner connection to people's daily small pleasures, that makes food such a powerful tool in political communication.

\section{ANALYSIS: CONNECTING COMFORT FOOD AND EXCLUSIONARY POPULISM}

In an era of increasing disintermediation of society, classical institutions such as political parties and the mainstream media have lost the hegemonic mediation between politics and "the people" (Enli and Rosenberg, 2018). As social media becomes a key piece in the apparently unmediated communication between populist leaders and their audiences, the importance of understanding their online political communication strategies becomes more striking. Previous research has pointed out that social media is an essential tool of communication between populist leaders and their audience (Blassnig et al., 2020; Bobba, 2018; Sorensen, 2018). This is because it enables a form of ubiquitous and apparently unmediated communication between political leaders and citizens, as well as more individualised communication between like-minded users. 
An interesting way of opening the analysis section is to look at the first post that Matteo Salvini publishes on his official Instagram account containing the 2019 European Elections slogan; a sort of official opening of his electoral campaign more than a month ahead of the official date. The post, although not food-related, contains two key elements that prove useful for contextualising the rest of the posts during the European electoral campaign: common sense and people's empowerment. If one reads the accompanying text, we find out that the post is not only populist in its appeals to "the people" but also for its antielitist stance: "A Europe that puts peoples first and not bureaucrats, bankers, the small boats do-gooders [in reference to those who defend immigrants, such as Carola Rackete]" ("Un'Europa che metta al primo posto i popoli e non burocrati, banchieri, buonisti o barconi").

\section{Image 1. Salvini launches the EU electoral campaign}

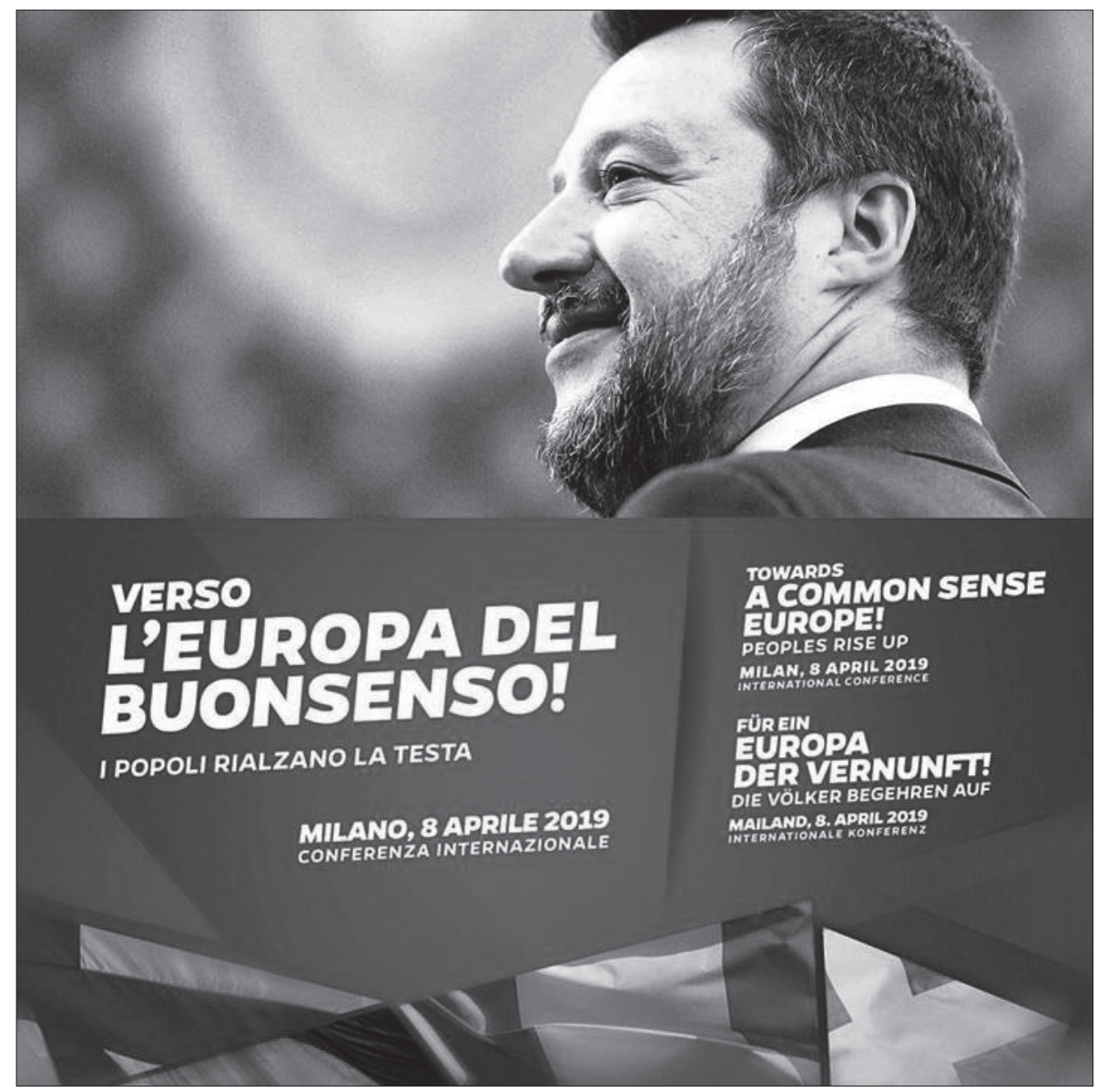

Source: @matteosalviniofficial, 6 April 2019, retrieved from

$<$ https://www.instagram.com/p/Bv7FkWlhQTo/?utm_source=ig_web_copy_link>. 
This post will introduce the first category of this section, that is, the way in which Matteo Salvini constructs his social media persona and "his people" through his food posts. The people who surround Salvini in pictures are not just common people, but good people. The meaning of "good" is explained in a post in which he poses with a family during a rally in defence of Italian products: "Normal people, decent people, nothing to do with those who mess with the police!" (1 May 2019). The kindness of his followers is something that, he avows in the post, moves him deeply. Perhaps one of the most interesting posts is precisely one of Nutella. The publication shows a composition of old Nutella advertisements with images of kids happily enjoying a toast with the spread. The first image, though, is not a kid, but an adult Salvini posing as a kid. In a clear defiance of the bourgeois taste, he proudly shares his childish craves as a way of appearing more human, more authentic in the face of his followers. The vintage look, the appeals to family, tradition, childhood happy moments, they all make the post stand out. And so does the accompanying text: "Sweet Easter to you Friends! And a nice slice of bread and Nutella (which turns 55 today, best wishes!) for the friendly, happy and welcoming left-wing millionaires Fazio and Saviano". This mélange of greetings, tradition, religion and joy contrasts sharply with the punching irony of the post and his despise for those who identify with left-wing politics.

Image 2. Salvini poses while eating a Nutella toast

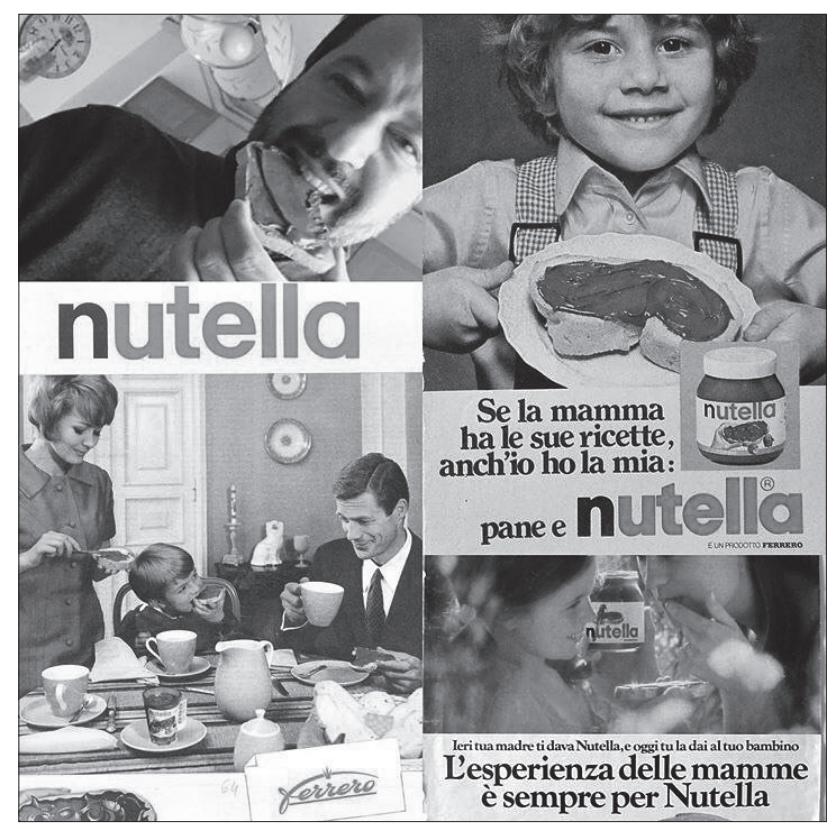

Source: @matteosalviniofficial, 20 April 2019, retrieved from $<$ https://www.instagram.com/p/BwfWfj1Bh2F/?utm_source=ig_web_copy_link>. 
Salvini's posts can be seen as part of a broader nationalist project of defining Italy and Italian food. The way he does so is by using food as a cultural trope that conveys authenticity. This element takes many shapes in his food posts: from a lack of colour filters to his posts with messy hair and an informal clothing style. An important element that conveys authenticity is the rough aesthetics of the posts. However, he also finds ways of making the accompanying text more authentic: the lack of commas, the exclamation points or the systematic use of smiling emojis, sometimes sending a kiss to his Amici.

Salvini cooks affordable comfort food, which is also a feel-good food. The presence of positivity and good mood transpires through comforting photos (in the food, in Salvini's clothing) of an always smiling Salvini, but also through the use of humour, greetings and happy emojis. Something that is very particular in his Instagram is the way he addresses his followers: Amici, or Friends, with a capital A (or F). This capitalisation of the word, as if it was a first name, conveys the idea that his friends are all-encompassing, and his enemies few.

Food is a cultural marker that connects people in terms of time and space, bringing about memories of celebrations, family recipes or childhood favourites. As Ascione (2018: 308) puts it, "[e]ating together is the foundation of the cultural identity and continuity of communities throughout the Mediterranean basin. It is a moment of social exchange and communication, an affirmation and renewal of family, group or community identity". It is not by chance that populist leaders post images of traditional "comfort food", such as a nice dish of pasta - any food that makes us feel good by bringing about familiar, nostalgic appeals (Contois, 2018).

\section{A Good Father}

References to tradition often appear linked to family traditions that have religious connotations. For instance, the 20th April he posted an image of an Easter egg decorated by his daughter —an Italian tradition. In other instances, tradition is just implied in habits that he has inherited from his relatives and which he transfers to his kids, such as drinking milk sweetened with honey before bed (12th April). Tradition is never given, but "an act of manipulation" by which we select and contextualise certain behaviours as such (Ascione, 2018: 304).

The type of comfort food in Salvini's posts is clearly about tradition, family roots and community in the face of the quick pace, frustration and isolation of modern life. The use of food as a cultural trope mobilises people's cultural identity, facilitating shared emotions and community bonding. More precisely, food has "intangible qualities" as it is able to create a state of mind that makes us feel at ease in a familial environment (Contois, 2018). Posts of him cooking for his kids, or his kids cooking with him, are common in Salvini's Instagram posts. Despite his fast-paced life, the leader presents himself as someone who fulfils his familial duties, finding time for disconnecting from politics and dedicating his breaks to his kids.

The interesting element is that Salvini's kids are not the only ones to share a meal with him. His meals, he shares them with his followers, who are friends, almost family. The analysis of his food posts reveals that they often coincide 
138 with Salvini's breaks from work during or after a busy day. He appears, then, as a ubiquitous leader who spends his day working for the future of Italians and does not abandon them for a moment. Even when he is resting, when he has his coffee break or his lunch break, he voluntarily shares them with his followers through his social media accounts. This creates an image of full dedication, even reminiscent from populist paternalism.

\section{Image 3. Salvini poses drinking a "good coffee" in the morning}

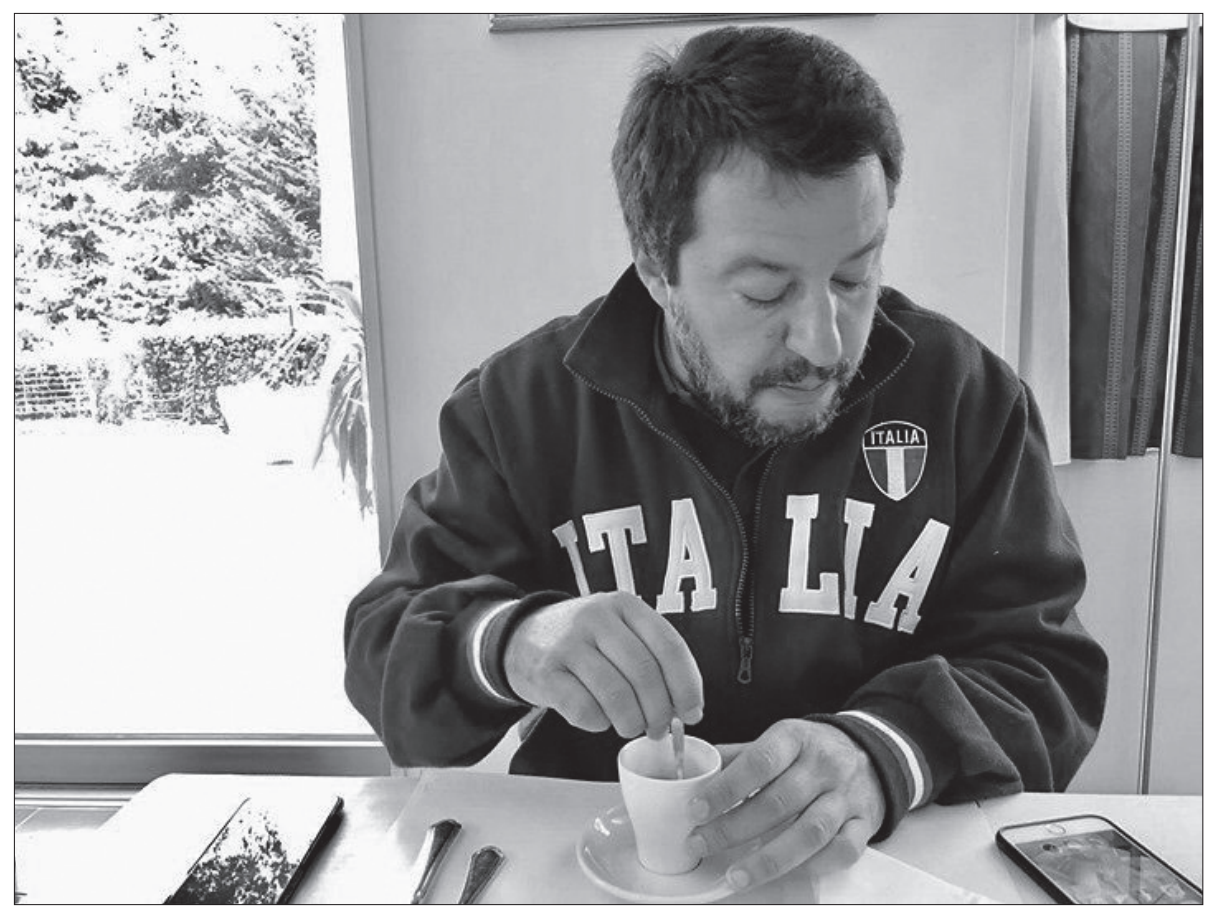

Source: @matteosalviniofficial, 9 May 2019, retrieved from

$<$ https://www.instagram.com/p/BxO8_CLhIP8/?utm_source=ig_web_copy_link>.

A still visibly sleepy Salvini writes: "Italian sweatshirt, a good coffee and here we go!", he posts, followed by a smiling emoji and the \#Italiansfirst hashtag. Embracing Italians is, for Salvini, sharing his life with them while he works (with two mobile phones, apparently) and while he enjoys a break.

\section{Friend of the "Ressented"}

Salvini constructs particular foodscapes that are at the crossroads between Italian food, memory, tradition and popular culture. When populist leaders post images of familial and traditional food, they are evoking feelings of trust and security. Comfort food becomes a cultural trope able to appeal to the so-called "losers of globalisation", making them feel recognised in the values and aesthetics of the farright. The support for tradition and for nationhood mobilises their nostalgia for 
better times and offers them a way of feeling safe within their communities while legitimising their ressentiment against the threat of foreign and bourgeois taste.

Salvini's posts evoke positive emotions, comfort, satisfaction, relax, easy feelings of pleasure. However, an in-depth look allows to identify clear appeals to ressentiment, such as anger and anxiety that are addressed to his enemies. The data shows that, while food becomes an empty signifier that connects emotionally with the people, the accompanying text of food posts evokes ressentiment. The combination of food photographs and text sheds light in far-right leaders' political communication strategy: first, mobilising support through identityevoking symbols, such as comfort food, then turning those symbols against an "other", whether the intellectual left or activists — such as Carola Rackete".

\section{The “Good Taste” of Salvini's Enemies}

An interesting element in Salvini's food posts is his jouissance in the face of his enemies. It is common to see images of the far-right leader dedicating a toast to those who dislike him, to an evil "other" who wishes him the worst. For instance, a photo of him enjoying a sunny day with a glass of Spritz and some roast peanuts, and toasting for those who dislike him, accumulates over eighty thousand likes, making it one of the most popular food-related posts (19th April). Ironically, he appears as fighting meanness with kindness, hate with love. His posts denote a Salvini who enjoys life no matter what, who thrills in the face of adversity: the more "they" attack him, the more he surrenders to the simple pleasures of life. In this context, food posts appear as a way of truly embracing pleasure, joy, and life.

Image 4. Salvini posts a low-quality picture of a dessert, yet talks about his enemies

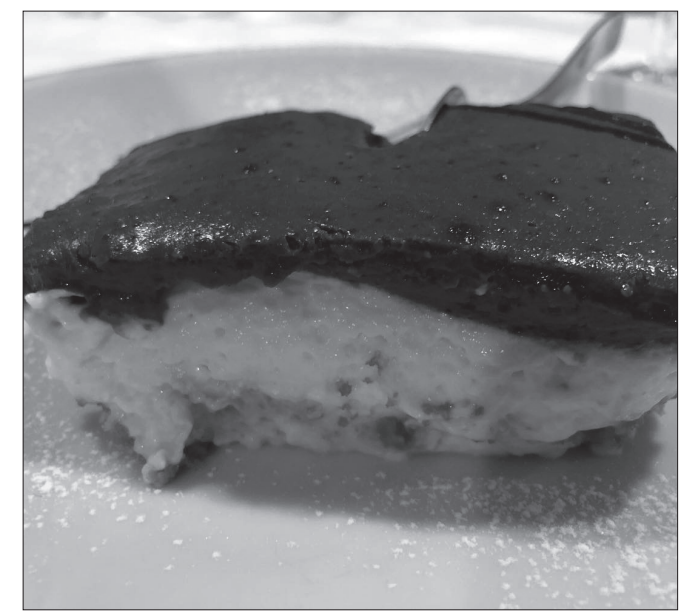

Source: @matteosalviniofficial, 6 May 2019, retrieved from <https://www.instagram.com/p/BxHGwWrn-le/?utm_source=ig_web_copy_link>. 
140 In the post above, Salvini posts a not-so-flattering image of zuppa inglese, a dessert typical from Piemonte, followed by this sentence: "The more they attack and threaten me, the more they give me the force and the will to work for defending Italians", followed by a smiling emoji. This explains his enjoyment of difficult times as a kind of sacrifice for "his people", very much in line with his nationalist and populist discourse.

\section{The European Union}

The European Union is highly present in Salvini's Instagram posts throughout the electoral period but not only in electoral posts. Salvini's particular idea of a people-led yet exclusionary Europe is evoked when he posts images of Italian dishes or, even more, Italian raw materials. The most striking example is that of his Nutella polemics, in which his consumption of even his most appreciated guilty pleasure is conditioned to the pureness of its composition: only Italian products. His rejection of consuming Turkish hazelnuts is presented in a way that hides racist connotations under an unconditional love for the people and the nation: helping Italian farmers. However, there is one type of posts that is systematically contextualised within European electoral debates: fruit. Many of Salvini's posts of fruit during the campaign bring the public a clear message: eat Italian.

\section{Image 5. Video in which Salvini defends Italian local products}

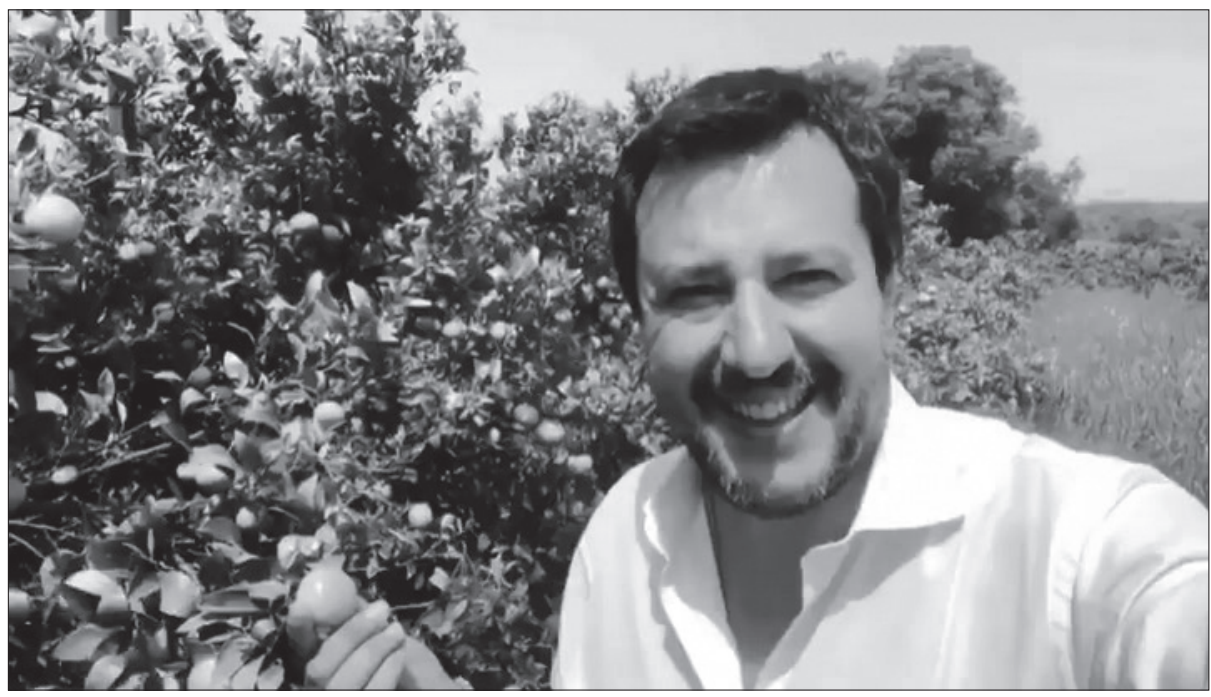

Source: @matteosalviniofficial, 26 April 2019, retrieved from

<https://www.instagram.com/p/BwuGzpRlyig/?utm_source=ig_web_copy_link>.

In this post, Salvini praises Sicilian oranges and asks his followers "to GIVE HIM A HAND in order to defend, with tooth and nail, the richness of our land and our sea!", followed by the \#primaitalia slogan. This is a pattern that he follows in the rest of fruit posts, which always convey the idea of a "fight" between Italians 
and the European Union the result of which will play out, to great degree, during the elections. This message can also be recognised in the post below, in which voting for him is discursively constructed as voting for Italy. Voting Lega, he says, is voting Italian, discursively appropriating the nation for his political gain.

\section{Image 6. Salvini defends Italian agriculture during the electoral campaign}

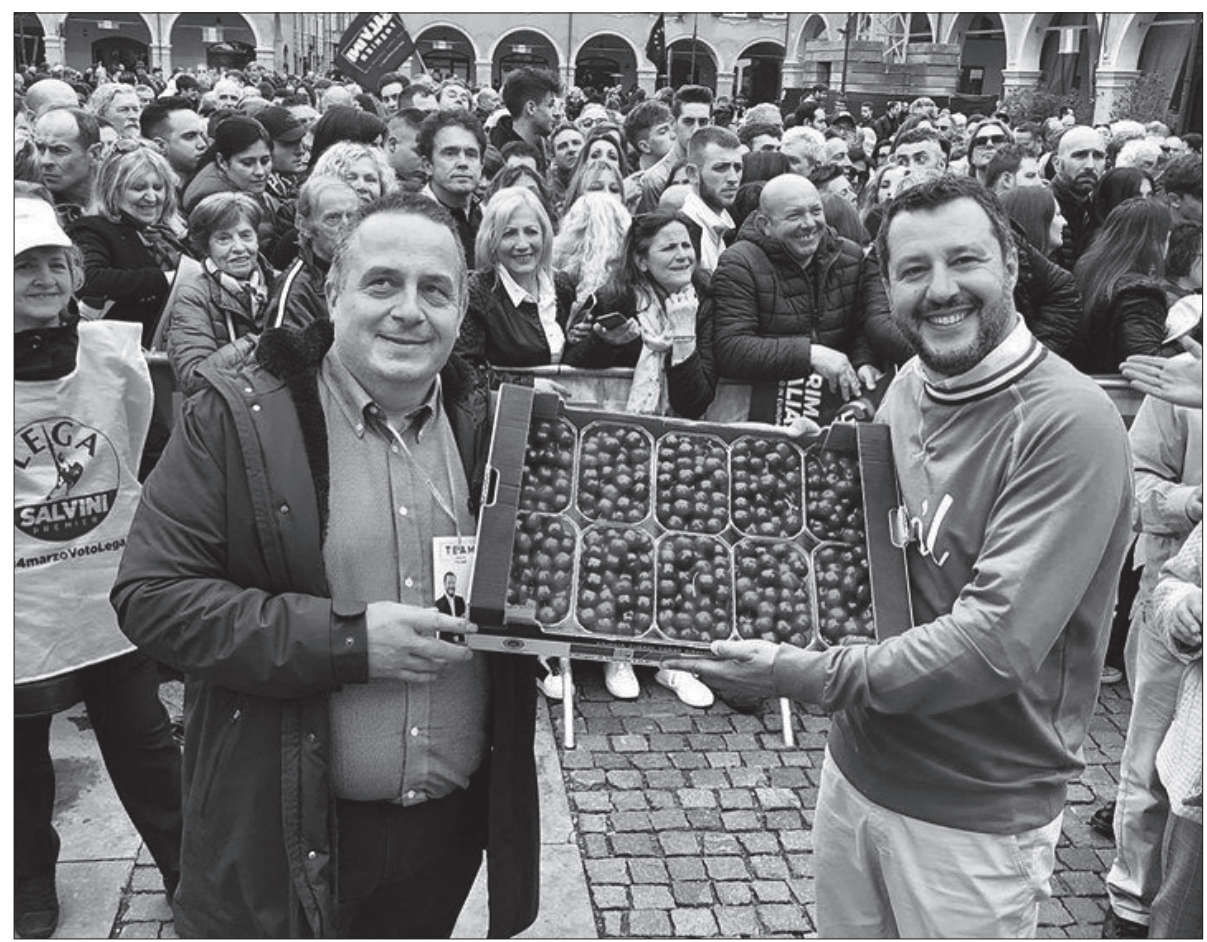

Source: @matteosalviniofficial, 19 May 2019, retrieved from

<https://www.instagram.com/p/Bxpc9oRleyC/?utm_source=ig_web_copy_link>.

Salvini's posts reveal that he uses food as a symbol of social class and national identity. Not surprisingly, the slogan "Italians first" is a common hashtag that accompanies Salvini's food posts. The Lega's "Italians first" has seen politicians passionately defending made-in-Italy products as an extension of nationalism and exclusionary populism. Therefore, Salvini's "good" eating practices need to be interpreted against the backdrop of his nationalist and chauvinistic ideology: the Made-in-Italy, the home-made and the self-made are interlinked in his food posts and in his social media persona.

\section{The Racialised "Other"}

Social media performances of authenticity are a useful tool for performing a given identity based on one's position towards taste, creating boundaries of inclusion and exclusion (Mudde and Kaltwasser, 2013; Laclau, 2005; LeBesco 
and Naccarato, 2008). While a racialised "other", such as immigrants, refugees or asylum seekers, is not directly addressed in Salvini's food posts, it is often evoked through references to those who defend immigrants' rights, who are discursively constructed as his enemies. However, the easiest way to find those excluded from his nationalist discourse is through the composition of his Instagram account. The images below, all posted the same day (6th May), offer a glimpse into the type of visual discourses that appear in Salvini's Instagram account during the European electoral campaign: politics, food and illegal immigrants. Clearly, a foodscape characterised by exclusionary nationalism that makes negative normative assumptions about racialised subjects that are very much in line with the Lega's far-right discourses.

\section{Image 7. Glimpse of Salvini's Instagram pictures during the campaign,} all posted the same day

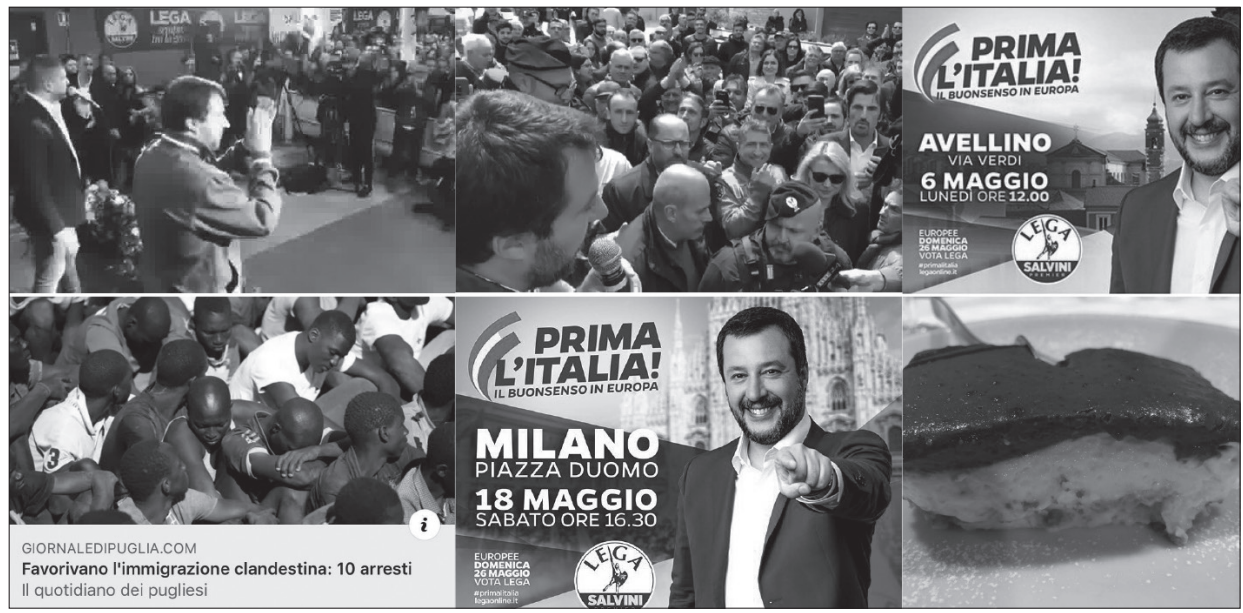

Source: @matteosalviniofficial, 6 May 2019, retrieved from $<$ https://www.instagram.com/p/BxHlwHGIZV2/?utm_source=ig_web_copy_link> $<\mathrm{https} / / /$ www.instagram.com/p/BxHgO6fhiEh/?utm_source=ig_web_copy_link> $<$ https://www.instagram.com/p/BxHXjWjhISb/?utm_source=ig_web_copy_link> <https://www.instagram.com/p/BxHPsr9hp0Z/?utm_source=ig_web_copy_link> $<$ https://www.instagram.com/p/BxHKv2Mhv_v/?utm_source=ig_web_copy_link> $<$ https://www.instagram.com/p/BxHGwWrn-le/?utm_source=ig_web_copy_link>.

\section{The Bourgeois Taste}

Perhaps the most visually relevant elements of Matteo Salvini's food posts on Instagram are his appeals to "the people" in terms of exclusionary nationalism, as in the example above, but also social class. The politicisation of food serves a populist strategy that aims at bringing the populist leader and its followers against the bourgeois taste of the elite. Bourdieu considers that there are differences in the judgement of taste between the working class and the bourgeoisie. Our taste in food does indeed speak to our class position, although at times in unexpected ways (Johnston and Goodman, 2015: 207). 
For instance, Emily Contois (2018) has analysed Guy Fieri's popular food show Flavortown, which serves an attempt "to reach Americans who feel left behind by the nation's cultural (or, in his case, culinary) elite"; to those who feel socially and culturally disenfranchised in a globalised world (Contois, 2018: 56). Just as Fieri's programmes, by invoking authentic food Salvini evokes a particular image of the heartland and the common people that is far from all-encompassing. A part of the people is invoked, while the rest is excluded. An important element to note is that the construction of identity always comes with the construction of difference. Therefore, posts of food on Instagram play a role in the construction of a particular Italian identity that advances the goals of far-right populist leaders against the traditional political class and the intellectual elite. This construction of boundaries of belonging goes in line with the "populist animus", which seeks dividing rather than uniting the people altogether (Canovan, 1999).

The analysis of Salvini's food posts reveals that he situates himself on the side of low culture, posting photos of modest, ordinary, dull food following clumsy, blunt and crude aesthetics. From Bourdieu's (1984: 468) perspective, this situates him on the side of the dominated masses and opposed to the high, fine, exclusive and brilliant foodways that are associated to the traditional political elite. For instance, we have shown a Salvini who reveals his guilty pleasures in a way that challenges elitist food trends, such as "food porn" aesthetics or health and environmental concerns. For politicians, revealing their infatuation is a way of sharing a weakness that connects to most people's weaknesses. It is not by chance that Salvini emphasis on having a sweet tooth for deliciously greasy food and desserts, even if they do not look so in appearance. Our ability to connect to their tastiness is precisely what makes Salvini's food posts so appealing: they evoke experiences that are so rooted in our memory, in our daily habits, that we automatically recognise their properties without the need to enhance them through food-pornish aesthetics. In the end, we all know the texture, the smell and the taste of a slice of pizza.

\section{The Rough Aesthetics}

The styling and online circulation of food photography has become a phenomenon endemic to social media (Dejmanee, 2015). However, far from the trendy Instagram culture of food porn, or progressive concerns for healthy living and climate change, far-right leaders often use Instagram to portray themselves surrounded by simple, comfort food. One way of understanding this political strategy is through the construction of comfort food as a cultural signifier that helps the leaders perform a class and nation-based rebellion against the expert, snobbish gourmet food culture of the traditional elite.

Why would Salvini post technically flawed pictures, blurry, crooked and burnt by an excess of light and in crooked frames? As we have seen, nothing about Salvini's food posts is visually mouth-watering. The appeal of the food posts lays in the ability of his followers to emotionally identify with them and to interpret the cultural codes that are embedded: memories of family, home, tradition, comfort; safety. What we see is a conscious deviance from trendy social media aesthetics, from elitism and for the bourgeois taste. The consistency across 
Salvini's food images suggests that he aims at creating a particular kind of (un) curated media image. Therefore, choosing to have a rough aesthetic is just a way of staging authenticity and spontaneity: casual, unrehearsed and seemingly uncalculated photos of his most private moments of joy and rest.

The apparently uncurated and lowbrow aesthetics of Salvini is essentially anti-intellectual, as opposed to the highbrow and polished pose of traditional politicians showing high culture consumption preferences. In Salvini's posts, we can find a rejection of the bourgeois moralistic standards of good taste and the elitist "disgust of the facile", of surrendering to simple pleasures (Bourdieu, 1984: 486). Instead, he constructs his political persona around easily accessible pleasures, such as a bowl of greasy pasta or a well-loaded toast of Nutella; pleasures that the bourgeoisie might qualify as "childish" or "primitive" and which have gained him public criticism from doctors and journalists. It is not by chance that the populist conception of Italian taste appears as casual, humble and easily accessible: that is, as democratic. A taste that is opposed to Bourdieu's bourgeois taste, which would be represented by foodies, crafty-hipsters, health gurus and well-travelled ethnic connoisseurs (Contois, 2018: 150).

\section{Image 8. Poorly taken food image in Salvini's Instagram account}

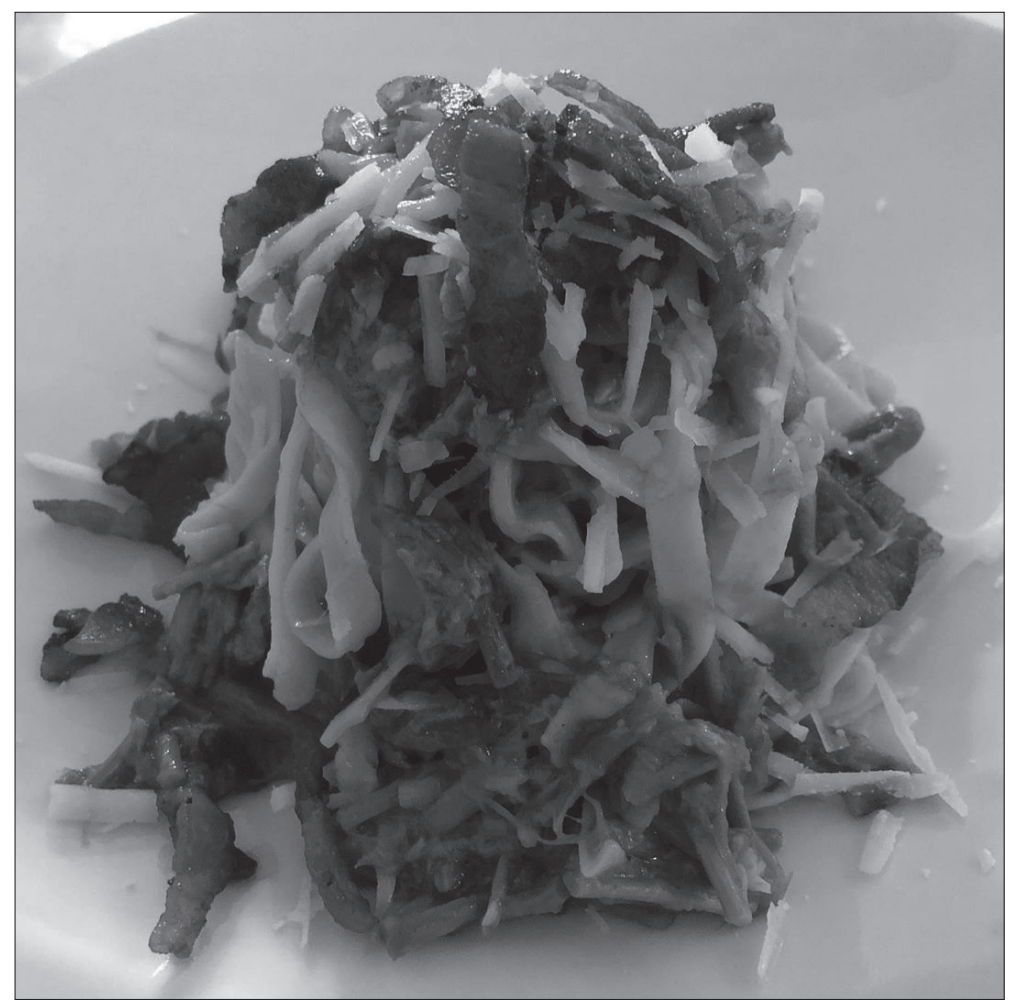

Source: @matteosalviniofficial, 6 June 2019, retrieved from

$<$ https://www.instagram.com/p/ByWF_FXoXhF/?utm_source=ig_web_copy_link>. 
The posts encompass an imperfect yet authentic Salvini that acknowledges his flaws through the imperfection of his food posts, showing a blemished aesthetics that differs from the bright, proper, and glossy characteristics of Instagram food trends (Shih, 2012). For instance, the lack of colour correction or filters contributes to the impression that posts are authentic, spontaneous, unedited and not privy to the expectations of the self-consciously polished Instagram aesthetic. Overall, Salvini's Instagram posts reveal the performance of authenticity and unpretentiousness through food as a political communication strategy (Contois, 2018: 150). What Salvini seeks is breaking away with the rules that associate politicians with high culture, identifying instead with a lowbrow aesthetics that coopt everyday cultural tropes.

\section{CONCLUSION}

This article has analysed the use of food posts in the official Instagram account of Matteo Salvini, a prominent far-right populist leader, during his 2019 European elections campaign. An analysis of the data reveals that food is given visual centrality in his posts but is never central from a discursive standpoint. Food appears as an empty signifier that sparks people's attention and emotional involvement in a good versus evil fight between "the people" (patriots, the earnest working-class) and a traditional, intellectual and political elite. The European Union appears, in this sense, as a double enemy, conveying not just threats to national unity and his \#Italiansfirst slogan, but also to the "taste" of the common man. Therefore, Salvini's food posts need to be understood as a political detachment from the traditional and elitist political class in an attempt to emotionally connect with his followers. Curiously enough, he does so on Instagram, a social network known for succulent representations of cuisine as "food porn". Yet, the rejection of elitism and food trends brings Salvini's food posts closer to the values of "food puritanism" that is, simplicity, tradition, authenticity, and immediacy beyond aesthetic values.

Making familiarity-based arguments allows political leaders to create boundaries that exclude the "bourgeois taste" of a foodie, intellectual elite that is accused of failing to properly perform class and nationalism. In a way, food becomes a familiar empty signifier, one able to encompass authenticity in political discourse. This pushes us to reconsider the culture of food porn on Instagram as the only way to instrumentalize food in a way that gets people's attention. Far-right populist leaders demonstrate that Instagram can also be a site for food populism, that is, the use of food to embody polarising populist constructions of the people in terms of nation and social class. Characterised by tradition and puritanism, food populism does not use the visual editing tools of Instagram -instead rejecting them altogether. Food is not the message itself, but a means to communicate the leaders' identity and political platform.

The analysis reveals that we can find elements of national pride and popular culture in Salvini' Instagram account in a way that foregrounds the symbolic power of food-as-nation, as a return to a pre-globalisation era that values nativism, 
tradition, and the "made in Italy". Similarly, he constructs his public persona as a common man with middle class aspirations who shares the socio-economic struggles of his followers. Therefore, the analysis of Salvini's Instagram account reveals the importance of food as a cultural trope that mediates a symbolic connection between far-right leaders and their voters.

When examining Matteo Salvini's food posts, one question keeps coming to my mind: why would somebody post images of food in the foodie social network par excellence, Instagram, and not do it in a food-pornish style? This chapter shows that political leaders' posts of food are never about just food. Salvini takes an exclusionary populist and anti-elitist stance by posting food images in the name of "the people" — that is, a nation of common people represented through food as a mythical unified whole that existed in a past era in which habits and traditions did not need to be justified. The leader uses social media to express annoyance with those who he perceives as questioning the status-quo: whether multiculturalism, race, gender, or environmental causes. Therefore, far-right politician's Instagram accounts use food as an empty signifier to invoke both positive emotions of familiarity and negative emotions of ressentiment against the political and intellectual elite. Matteo Salvini is not the only one: so do Jair Bolsonaro in Brazil, Nigel Farage in the United Kingdom or Tomio Okamura in the Czech Republic. And of course, using food as a means of bonding with "the people" is not only a far-right political communication strategy. One only needs to follow Alexandria Ocasio-Cortez on Instagram to realise the importance of everyday popular culture in connecting politicians with their followers. Therefore, what this study shows is the need to take into account the role of cultural tropes, such as food, but also sports, in the mediation of populist messages to emotional appeals that connect them with their followers. The politicisation of everyday, familiar symbols sheds light on the use of popular culture as an empty signifier that serves the political discourse of the populist simplistic yet flashy recipes for solving people's problems. Stop eating Nutella (if you can).

Sara García-Santamaría (garcias.sara@gmail. com) is a doctorin Journalism Studies (University of Sheffield, UK). She works as an Assistant Professor at Ramon Llull University (Barcelona, Spain). Here research focuses on three areas: populism and political communication, social networks and authenticity in a post truth era and independent journalism in transitional contexts. Sara is vice-chair of the Political Communication Section at the International
Association for Media and Communication (IAMCR) and a member of the research team Media Flows (Spain). She is co-editor of Media and Governance in Latin America: Towards a Plurality of Voices (Peter Lang, 2020) and Cuba's Digital Revolution: Citizen Innovation and State Policy (University of Florida Press, 2021), as well as having published a number of publications in international peer-review books and journals. 


\section{References}

Albertazzi, Daniel; Giovannini, Arianna, and Seddone, Antonella (2018). "No Regionalism Please, We Are Leghisti!' The Transformation of the Italian Lega Nord under the Leadership of Matteo Salvini". Regional \& Federal Studies, 28(1), pp. 1-27.

Ascione, Elisa (2018). "Food and Cultural Heritage: Preserving, Reinventing, and Exposing Food Cultures". In: LeBesco, Kathleen and Naccarato, Peter (eds). The Handbook of Food and Popular Culture. London: Bloomsbury.

Belasco, Warren J. (1989). Appetite for Change: How the Counterculture Took on the Food Industry. Ithaca: Cornell University Press.

Bell, David and Valentine, Gill (1997). Consuming Geographies: We Are where We Eat. London: Routledge.

Belpoliti, Marco (2019). "La dolce festa della Nutella: Il mondo nel vasetto di vetro. Oggi la Giornata internazionale". La Reppublica, 5 February 2019. Available at: <https://www. repubblica.it/sapori/2019/02/05/news/la_dolce_ festa_della_nutella_il_mondo_nel_vasetto_di_ vetro-218322437/>. Accessed 28 March 2020.

Blassnig, Sina; Ernst, Nicole; Engesser, Sven, and Esser, Frank (2020). "Populism and Social Media Popularity. How Populist Communication Benefits Political Leaders on Facebook and Twitter". In: Taras, D. and Davis, R. (eds.). Power Shift? Political Leadership and Social Media. London: Routledge, pp. 97-111.

Bobba, Giuliano (2018). "Social Media Populism: Features and 'Likeability' of Lega Nord Communication on Facebook". European Political Science, 18(1), pp. 11-23.

Bourdieu, Pierre (1984). Distinction. A Social Critique of the Judgement of Taste. Harvard University Press.

Bracciale, Roberta and Martella, Antonio (2017). "Define the Populist Political Communication Style: The Case of Italian Political Leaders on Twitter". Information, Communication \& Society, 20(9), pp. 1310-1329.
Canovan, Margaret (1999). "Trust the People' Populism and the Two Faces of Democracy". Political Studies, 47(1), pp. 2-16.

Carpentier, N. and Cleen, Benjamin de (2007). "Bringing Discourse Theory into Media Studies". Journal of Language and Politics, 6(2), pp. 265-293.

Carvalho, Anabela (2008). "Media(ted) Discourse and Society". Journalism Studies, 9(2), pp. 161-177.

Cleen, Benjamin de and Stavrakakis, Yannis (2017). "Distinctions and Articulations: A Discourse Theoretical Framework for the Study of Populism and Nationalism". Javnost - The Public, 24(4), pp. 301-319.

Contois, Emily J. H. (2018). "Welcome to Flavortown: Guy Fieri's Populist American Food Culture". American Studies, 57(3), pp. 143-160.

Corvo, Paolo (2015). Food Culture, Consumption and Society. New York: Palgrave Macmillan.

Dejmanee, Tisha (2015). "'Food Porn' As Postfeminist Play: Digital Feminity and the Female Body on Food Blogs". Television and New Media, 17(5), pp. 429-448.

Eklundh, Emmy (2019). Emotions, Protest, Democracy. Collective Identities in Contemporary Spain. New York: Routledge.

Elliott, Charlene (2008). "Consuming the Other. Packaged Representations of Foreignness in President's Choice". In: LeBesco, Kathleen and Naccarato, Peter (eds). Edible Ideologies. Representing Food and Meaning. Albany: State University of New York Press, pp. 179-198.

Engesser, Sven; Ernst, Nicole; Esser, Frank, and Büchel, Florin (2017). "Populism and Social Media: How Politicians Spread a Fragmented Ideology". Communication \& Society, 20(8), pp. 1109-1126.

Enli, Gunn and Rosenberg, Therese (2018). "Trust in the Age of Social Media: Populist Politicians Seem More Authentic". Social Media \& Society, pp. 1-11. 
García-Santamaría, S. (2020, Forthcoming). "Posing with the People: Food Porn and the Far-Right in a Post-Truth Era". In: Contois, E. and Kish, X. (eds.). You Are What You Post: Food and Instagram. Bloomsbury Academic Press. In Press.

Giovine, Michael A. di (2014). "The Everyday As Extraordinary: Revitalization, Religion and the Elevation of Cucina Casareccia to Heritage Cuisine in Pietrelcina, Italy". In: Giovine, Michael A. di and Brulotte, Ronda L. (eds). Edible Identities: Food As Cultural Heritage. Ashgate, pp. 77-92.

Hayes-Conroy, Jessica and Hayes-Conroy, Allison (2013). "Veggies and Visceralities: A Political Ecology of Food and Feeling". Emotion, Space and Society, 6(1), pp. 81-90.

Ibrahim, Yasmin (2015). "Food Porn and the Invitation to Gaze: Ephemeral Consumption and the Digital Spectacle." International Journal of E-Politics, 6(3), pp. 1-12.

Iyengar, Shanto and Westwood, Sean J. (2015). "Fear and Loathing Across Party Lines: New Evidence on Group Polarization." American Journal of Political Science, 59(3), pp. 690707.

Johnston, Josée and Goodman, Michael K. (2015). "Spectacular Foodscapes". Food, Culture and Society, 18(2), pp. 205-222.

Kędra, Joanna and Sommier, Mélodine (2018). "Children in the Visual Coverage of the European Refugee Crisis: A Case Study of the World Press Photo 2016". Journal of Applied Journalism and Media Studies, 7(1), pp. 37-58.

Klassen, Karen Michelle; Borleis, Emily; Brennan, Linda; Reid, Mike; McCaffey, Tracy, and Lim, Megan S. C. (2018). "What People 'Like': Analysis of Social Media Strategies Used by Food Industry Brands, Lifestyle Brands, and Health Promotion Organizations on Facebook and Instagram". Journal of Medical Internet Research, 20(6), pp. 1-9.

La Reppublica (2019). "Salvini fa un passo inietro: 'Addolcisco la giornata con una fetta di pane e Nutella'”. La Reppublica, 6 December 2019. Available at: <https://www.repubblica. it/politica/2019/12/06/news/nutella_salvini242746679/>. Accessed 18 March 2020.

Laclau, Ernesto (2005). On Populist Reason. London: Verso.

Laclau, Ernesto and Mouffe, Chantal (1984). Hegemony and Socialist Strategy: Towards a Radical Democratic Politics. London: Verso.

LeBesco, Kathleen and Naccarato, Peter (2008). "Julia Child, Martha Stewart, and the Rise of Culinary Capital". In: LeBesco, Kathleen and Naccarato, Peter (eds.). Edible Ideologies. Representing Food and Meaning, pp. 223-238. Albany: State University of New York Press.

Mejova, Yelena; Haddadi, Hamed; Noulas, Anastasios, and Weber, Ingmar (2015). "\#foodporn: Obesity Patterns in Culinary Interactions". ACM Conference on Digital Health (DH).

Minkenberg, Michael (2003). "The Renewal of the Radical Right: Between Modernity and Anti-Modernity". Government and Opposition, 35(2), pp. 170-188.

Mudde, Cas and Rovira-Kaltwasser, Cristóbal (2013). "Exclusionary vs. Inclusionary Populism. Comparing Contemporary Europe and Latin America". Government and Opposition, 48(2), pp. 147-174.

Naccarato, Peter and Lebesco, Kathleen (2012). Culinary Capital. London: Bloomsbury.

Palmer, Gareth (2004). "'The New You': Class and Transformation in Lifestyle Television". In: Holmes, Sue and Jermyn, Deborah (eds.). Understanding Reality Television. New York: Routledge, pp 173-190.

Paxson, Heather (2013). The Life of Cheese. Crafting Food and Value in America. Berkeley; Los Angeles: University of California Press.

Pink, Sarah; Horst, Heather; Postill, John; Hjorth, Larissa; Lewis, Tania, and Tacchi, Jo (2016). Digital Ethnography. Principles and Practice. London: Sage.

Ranciere, Jacques (2010). Dissensus. On Politics and Aesthetics. New York: Continuum Books. 
Salmela, Mikko and Scheve, Christian von (2018). "Emotional Roots of Right-Wing Political Populism". Humanity \& Society, 42(4), pp. 434-454.

Shih, Stephane (2012). "Current Food Photography Styles and Trends: A Cake Case Study." Desserts for Breakfast, 12 June 2019. Available at: <https://www.pinterest.ca/pin/ $175499716702428706 /$ ?autologin=true>.

Sorensen, Lone (2018). "Populist Communication in the New Media Environment: A Cross-Regional Comparative Perspective". Palgrave Communications, 4(1), pp. 48-60.
Soroka, Stuart; Young, Lori, and Balmas, Meital (2015). "Bad News or Mad News? Sentiment Scoring of Negativity, Fear and Anger in News Content". ANNALS, 659(1), pp. 108-121.

Ulin, Robert C. (2013). "Terroir and Locality: An Anthropological Perspective". In: Black, Rachel and Ulin, Robert C. (eds). Wine and Culture. Vineyard to Glass. Bloomsbury, pp. 67-84.

Waisbord, Silvio (2013). Vox Populista: Medios, Periodismo y Populismo. Barcelona: Gedisa. 